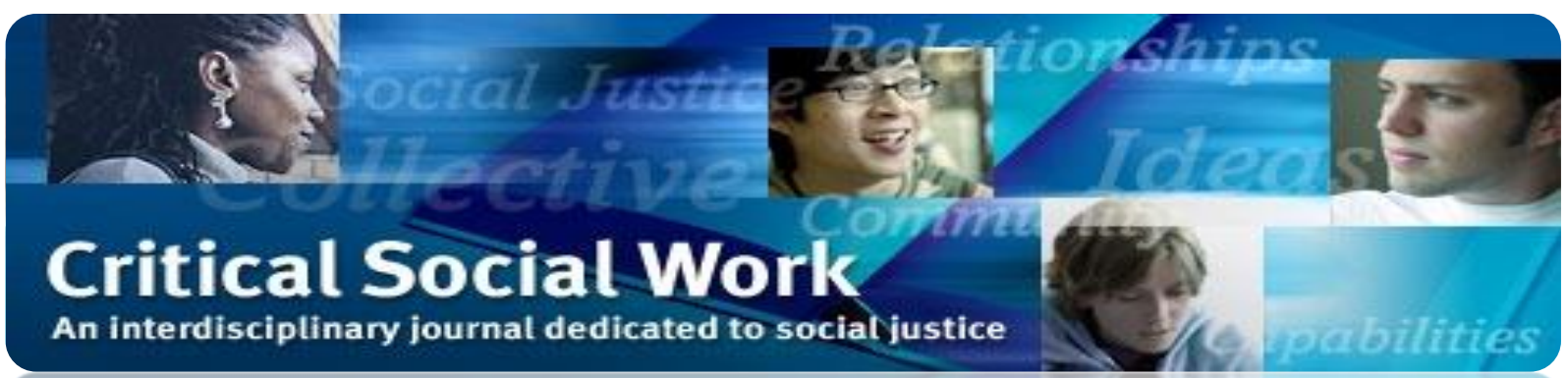

Critical Social Work

School of Social Work

University of Windsor

401 Sunset Avenue

Windsor, Ont.

Canada N9B 3P4

Email: cswedit@uwindsor.ca

Publication details, including instructions for authors and subscription information can be found at: http://uwindsor.ca/criticalsocialwork

Link to article:

http://www1.uwindsor.ca/criticalsocialwork/ReadingWorldSW

Critical Social Work, 2015 Vol. 16, No. 1 


\title{
Reading World Social Work Day 2010 through Multi-modal Analysis
}

\section{Critical Social Work 16(1)}

\author{
Tara La Rose ${ }^{1}$ \\ ${ }^{1}$ Trent University, Oshawa Campus
}

\begin{abstract}
Author Note
Acknowledgements: This research was supported in part by an Ontario Graduate Scholarship. The author wishes to thank: Maureen La Rose, Nancy Jackson, Donna Baines, Peter Sawchuk, Albina Veltman, Barbara Heron and Yvonne La Rose.
\end{abstract}

\begin{abstract}
This paper considers World Social Work Day 2010, a digital media story created and shared on YouTube by the International Federation of Social Workers. Multi-modal analysis is used to reveal the multi-vocal nature of the text and to consider the particular social work discourses used in this digital narrative. Connections between and across digital texts are used to explore the capacity of digital media to produce multiple meanings and to allow texts to exist in multiple contexts simultaneously. Post-structural perspectives framing this analysis encourage consideration of the potential meanings of globalization in social work, particularly when narrative texts are shared via online digital media environments and interpreted by both intended and unforeseen audiences.
\end{abstract}

Keywords: multi-modal analysis, digital media storytelling, globalized social work, Internet research 
World Social Work Day 2010 is a digital media narrative text created and shared on YouTube by the International Federation of Social Workers (IFSW). This narrative may be understood as a digital address from the IFSW to the global social work community. As a digital address, the sharing of this narrative is a practice of 'affinity' (Lange, 2009) designed to promote connections between the IFSW and the audiences who view this text (Lundby, 2008). These connections are made through the presentation of particular social work discourses, articulated in and through multiple communication modes. This paper seeks to consider the complex processes present in the creation and sharing of digital texts, such as World Social Work Day 2010 in an effort to understand how meaning[s] is[are] made through these texts and experienced by the audiences who bear witness to these narratives.

Deconstructing and analysing this digital narrative may be considered as a kind of research case study, serving as an example of the potential of Internet based communication for social work. Furthermore, this type of analysis suggests potential research activities that may flow out of social workers' use of digital media communications. The IFSW's use of digital media and YouTube to convey their message brings with it meanings that enhance, shape, mediate and mediatize social work (Lange, 2009; Snickars \& Vondreau, 2009).

The communication modes employed in this narrative include (but are not limited to) genre, words spoken, images shown, and the YouTube environment surrounding the narrative (Baldry \& Thibault, 2006; Lundby, 2008; Snickars \& Vondreau, 2009). Each of these modes, individually and taken together, provide audiences with meanings about social work as a global profession and as a subjective position from the perspective of the IFSW. Using multi-modal analysis to deconstruct the text allows for consideration of the interactions that occur between the content and context of the story, illustrating the dynamics that unfold between the practice of creating stories and the reading of these stories, especially when global audiences tune-in to narratives via the Internet. The particular, situated positions presented and read through these interactions bring to life the concept of "poly-contextuality" (La Rose, 2012, p. 302) as an important meaning making process in the practice of social work digital communication and in social work more generally.

Digital media narratives or digital media stories like World Social Work Day 2010 are evolving communication forms. These communication techniques are being applied in a wide range of social work contexts. In clinical settings, story making is being used to explore identity construction and normative notions of self and as a tool for "giving voice" to marginalized people (Lundby, 2008). In community practice, these methods are facilitating empowerment, advocacy work, and community-based education (Boler, 2008; Lundby, 2008). In communitybased participatory research, story making is sometimes the process, sometimes the product, and frequently a method of collecting data (for example see: www.edu.yorku.ca/digitalstories/ and http://storycentre.wordpress.com/). Digital media storytelling is also receiving sanction from professional organizations, such as the Canadian Association of Social Work Education (CASWE) (http://www.caswe-acfts.ca), the National Association of Social Workers, the British Association of Social Workers, and the IFSW. These (and other) regulatory bodies are integrating the method into their communication, policy development, and engagement strategies. 
The complexity of digital media processes suggests the need for greater interdisciplinary connections between social work, communication studies, and digital media scholarship. On this basis, analysis of World Social Work Day 2010 drawing on the knowledge bases of communication and digital media scholarship is one approach to increasing social workers' digital literacy.Thus, Baldry and Thibault's (2006) perspective of multi-modal analysis was utilized in this case study, an approach common in applied linguistics, digital media, and communication studies research.

\section{Deconstruction through Multi-modal Analysis}

Multi-modal analysis relies on deconstruction as the starting point for analyzing complex texts. Digital media stories actualize the capabilities of digital technologies to facilitate multimodal and multi-vocal communication processes (Lambert, 2008; Lundby, 2008). Multi-modal analysis considers multiple layers of context present in texts and created through the convergence or combining of these layers and the environments in which texts are presented (Baldry \& Thibault, 2006; Lambert, 2008; Lundby, 2008; Reinsborough \& Canning, 2010).

Multi-modal analysis considers these layers as both independent conveyers of meaning and as interconnected elements in the overall meaning of the text. Furthermore, shifting contexts add yet more layers of meaning to specific modes and to the text as a whole. The method supports open readings, emphasizing possible and multiple meanings without foreclosing the range of potential meanings that might be read by different audiences and produced through different contexts (Baldry \& Thibault, 2006; Lange, 2009; Lundby, 2008).

Multi-modal analysis acknowledges the researchers' role in identifying and selecting the analytical categories relevant to the text in the structure of the analysis. On this basis, the researcher identifies specific modes and messages relevant to the specific content and context of the text, and to the goals of the overall research project. The categories chosen for this analysis of World Social Work Day 2010 highlight digital media, hypermedia, and digital storytelling research literatures (Baldry \& Thibault, 2006; Dicks, Mason, Coffee \& Atkinson, 2005; Lundby, 2008; Markham \& Baym, 2009) as well as social work scholarship emphasizing critical, antioppressive perspectives.

\section{Analyzing Digital Complexity}

Narratives generated through digital communication activities may be understood as more complex than other kinds of narrative texts (Lange, 2009; Lundby, 2008; Markham \& Baym, 2009). The capacity of digital technology to convey information on many levels at the same time and to do so with great speed is part of what brings about this complexity (Dicks et al., 2005; Lundby, 2008; Markham \& Baym, 2009). Digital narratives can be easily transmitted via Internet or cellular networks and therefore accessed by an almost infinite number of people simultaneously, repeatedly, and at a relatively low cost (Dicks et al., 2005; Kidd, 2010; Lundby, 2008). This potential for rapid and repeated access creates (in part) the poly-contextuality mentioned earlier (Baldry \& Thibault, 2006; La Rose, 2012). Texts may be linked or embedded in new media fields, moving or duplicating themselves (Dicks et al., 2005). For example, a text may first be shared using a YouTube channel and then may be shared secondarily to an online 
blog or website through the embedding of hypermedia links. This hyperlinking means the text now "exists" (or more accurately can be accessed) in multiple contexts simultaneously (Baldry \& Thibault, 2006; Dicks et al., 2005). Each of these environments adds a layer of context to the story, creating multiple meanings and (potentially) the convergence of those meanings creating still more layers of meaning[s].

\section{Situated Analysis}

Baldry and Thibault (2006) argue that research is a process of analysis shaped (in part) by the researcher's situated location. Therefore, we might understand this as another kind of context that affects meaning. Analysis is shaped by the particular disciplinary orientations brought to the research by the researcher; for example, the perspective of globalization brought to World Social Work Day 2010 by the IFSW. Thus, analysis is always informed by intertextual and intersubjective knowledge of both the focus/topic and method/process of the project (Baldry $\&$ Thibault, 2005). Researchers act to foreground and background particular aspects of the stories in the analysis, creating yet more layers of context.

For social workers, a social work analysis of digital texts may still mean foregrounding and backgrounding various elements in the text. Social Work is a diverse and contested field (Baines, 2011); 'social work analysis' may, therefore mean attending to ideological concerns, particular practice activities, or even particular practice outcomes (Adams, Dominelli \& Payne, 2009; Baines, 2011; Mullaly, 2010). Social workers operating from different orientations to practice (e.g. anti-oppressive practice versus systems theory) may understand these as fundamentally different in terms of both process and outcome. In an international context, this may become more complex as particular cultural understandings and epistemological concerns reflecting regional knowledge, histories or circumstances create yet more layers of meanings within the story, which may or may not be visible to the audience[s].

\section{Analyzing World Social Work Day 2010}

The study goals and perspectives were influenced by the inter-textual and inter-subjective knowledge brought with me, as the researcher of this project. Therefore, this analysis of World Social Work Day 2010 begins with attention to several specific modes of communication present in the text. The YouTube channel containing this story creates a frame around the text, creating a layer of meaning that contextualizes this story. This is a part of informing audiences about the text, sharing with them potential information, such as how, when, why, and by whom the story was shared. What is seen and heard in this narrative converges, creating meaning, and the convergence of these sounds and images shifts and changes meaning as well. The theoretical elements attended to in this text, emphasize post-structural understandings and considerations of subjection, discourse activation, and intertextuality as part of making meaning (Baldry \& Thibault, 2006; Dicks et al., 2005; Lundby, 2008; Markham \& Baym, 2009). The "constellation" of elements (Baldry \& Thibault, 2006, p. 7) assembled in this reading is but one way of reading 
this narrative; another researcher might emphasize different perspectives and elements in their analysis, bringing to life a unique and no less valid reading of the story.

Analysis of this story is also extended to include exploration of links made across texts (both digital and material/traditional). These links result in connections that deepen and/or broaden meaning. This "extension" across texts makes a thicker, richer story of the thinner narrative[s] contained in a singular reading of World Social Work Day 2010 (Dicks et al., 2005; Lundby, 2008, Markham \& Baym, 2009). The knowledge produced in other disciplinary contexts gives meaning to the materials included in World Social Work Day 2010, meanings that cannot be made with the material contained in this text alone, but which are eluded to indirectly through the content and contexts framed by the narrative.

\section{Analyzing YouTube as the Media Field}

The IFSW has elected to share the digital media story World Social Work Day 2010 through the media-sharing website, YouTube. This choice means the YouTube environment is an element that shapes our understanding of the story in particular ways (Snickars \& Vondreau, 2009). The functional elements of the YouTube environment serve as a container that holds the narrative; here TheIFSW channel (to access this channel go to www.YouTube.com and search TheIFSW), content searching utilities, and access controls each add layers of meaning to the digital media story (Baldry \& Thibault, 2006; Lange, 2009; La Rose, 2012; YouTube Essentials Guide, 2011).

As a digital space, YouTube is dynamic. It is part web-based environment, part digital media application, and part online searchable database of media (Lange, 2009; La Rose, 2012; Snickars \& Vondreau, 2009; YouTube Essentials Guide, 2011), thus World Social Work Day 2010 is contextualized in each of these (and potentially more) ways. YouTube users might be searching materials, and/or watching materials they have selected, and/or watching materials offered to them through the interactive infrastructure built into this website. Some participants (e.g., the IFSW) may go beyond the 'viewer' role by contributing digital materials to the site for online sharing; these contributing participants are commonly referred to as "Tubers" (Lange, 2009; YouTube Essentials Guide, 2011).

Analysis of any material on YouTube benefits from consideration of the manner in which materials are posted and shared. YouTube is a publicly accessible website with a database of digital media materials organized into a searchable database through the use of 'channels' (YouTube Essentials Guide, 2011). Tubers like the IFSW register with the site by creating a user channel before they can upload materials. Channels allow Tubers to store, organize, retrieve, and share digital content (YouTube Essentials Guide, 2011). Filters can be applied to the channels to restrict the level of access audiences have to channel content (YouTube Essentials Guide, 2011). The privacy permissions in YouTube are relatively stable when compared to other social media environments (e.g., Facebook), making the decision to share things publicly a conscious choice and process for Tubers. Many different categories of channels exist, some created by individuals, some by organizations, and many by major social institutions, such as governments, political 
parties, mainstream media outlets, and accredited schools of social work; the IFSW may be counted among these institutions.

The IFSW's choice of YouTube and their creation of an 'open' channel (TheIFSW) suggests that the IFSW's tubing practice is an outreach activity, designed to foster connections with the general public, to raise public awareness of their work, and to connect with social workers around the globe (Lange, 2009). These meanings can be assigned based on the digital media scholarship about YouTube that considers the effects and uses of digital media sharing in this environment (Lange, 2009; La Rose, 2012; Snickars \& Vondreau, 2009). Using YouTube in this way has meaning whether or not the IFSW held these intentions as they began to participate in YouTube.

\section{Post-structuralism and Situated Meaning}

My analysis of World Social Work Day 2010 emphasizes a critical social work orientation and therefore employs a post-structural lens. The perspective embraces a "deep suspicion of universal claims...[of]...singular readings as truth", and of "coherent narratives..." (Rosenberg, 2004, p. 36), encouraging tolerance of "paradoxes" and for scholars "to endeavour to hold contradictions, and to learn from what we might not otherwise have thought..."

(Rosenberg, 2004, p. 36). This perspective complements the philosophy of multi-modal analysis and digital media scholarship.

The idea of researching digital media texts as an act of knowledge creation/translation may be, in and of itself, an important act of social change, and this may well be a part of the IFSW's motivation for creating this digital narrative. Spivak (2004) challenges users to consider the contradictions created when the supremacy of written texts is maintained while claiming a desire for social change. Spivak argues that in order to bring about change, scholars and those claiming a desire for social change, must embrace new understandings of knowledge and new understandings of texts, a perspective that gets to the heart of critical social work. Similarly, Rosenberg (2004) emphasizes the need to open up our understandings and to consider the need for 'open readings' of content in both traditional and non-traditional texts. Possibility is a significant part of what these texts offer, possibilities and meanings that go beyond the limitations ascribed by the "authors' intent" (Rosenberg, 2004, p. 37). In reading World Social Work Day 2010 in this way, it is apparent that the text was created and tubed by the IFSW, and therefore, this story tells us something about social work and something about the IFSW, even if this information is constituted and shared in indirect ways. This text is formally presented as a text to mark "World Social Work Day"; this act brings to life the practice of "international observance days' declared and recognized by the United Nations (UN)

(see:www.un.org/en/events/index.shtml). Observance days are a form of "promotion", promoting in this case 'the profession' of social work and the values, causes and achievements of social workers. This promotion of the observance day reminds us of the IFSW's close relationship with the UN (Hick, 2001), a relationship that is marked in this digital story, just as the UN's choice to mark a 'World Social Work Day' illustrates the UN's support of the IFSW.

The recursive nature of these acts are revealed by considering that in marking World Social Work Day, the UN is in fact, framing social work by using official definitions created by 
the IFSW. In this description, the IFSW proudly emphasizes their connections with the UN, claiming a commitment to promote UN policies and agreements (IFSW, 2011). In this way, the UN's observance may be understood as a kind of sanction or support for the IFSW and for its articulation of the meaning of professional social work.

On the IFSW's official website, the role of the organization is described as the promotion of "social work as a profession, linking social workers from around the world and promoting... [their] participation ...in social policy and planning" (Hick, 2001, p. 65). The IFSW also describes itself as a professional organization representing more than "half a million social workers" (Hick, 2001, p. 65) in 80 different member nations (IFSW, 2011). The IFSW seeks to create formal systems of social work where they do not exist (IFSW, 2011), suggesting through this claims making that there are particular institutionalized ways of recognizing and knowing social work. This mandate overlooks the significant conflicts and tensions present in social work and more broadly in the context of human rights and social development practice by framing social work in some very particular ways.

Not all social workers embrace the IFSW's vision of social work. Alternative understandings argue professionalization has failed us (Baines, 2011; Mullaly, 2010). In these discourses, professionalization is understood to minimize social workers' status as employees. The daily lives of social workers are controlled by their employers and funders, often for purposes that do not reflect social work values (Baines, 2011; Mullaly, 2010). In this way, professional status may simply become another layer of regulation to be coped with (La Rose, 2012). Similarly, globalization (which is also promoted by the IFSW), is a process that is described by some critics as counteracting social work's aspirations and intentions, often producing exploitation and oppression, even in powerful 'developed' economies (Baines, 2011; Mullaly, 2010).

\section{Visual Elements}

In this message to the "world" from the IFSW, viewers are greeted with the image of Dr. David Jones, the (then) president of the IFSW. He is shown in a 'head and shoulders shot', his body visible from mid-chest to the top of his head, framed against the background of a blue sky. Behind the President, we see many different kinds of buildings all clustered closely together. They range from well-built buildings shown in the top third of the screen, to 'shanties' and makeshift buildings constructed from wood and corrugated metal shown in the bottom third of the screen. This backdrop is an image remaining through most of the story, it is generally static, but from time to time, slight movements occur as the camera operator attempts to show the length and depth of the space behind the President who stands looking pale and pensive, alone in the sunshine.

\section{Speech and Metaphor}

This silent image is made more complex by the introduction of sound in the form of speech. The President begins to narrate this image for us, informing us the backdrop he stands before is "a slum". He tells us that he is standing "in this location" in "the Mathare Slum" to provide viewers with a visual metaphor about social work and to mark World Social Work Day. 
He tells us that this location is also proximal to a hospitality and tourism training centre which sits adjacent to the slum but which is not visible to the audience. He describes this hotel training centre as affording "luxury" to the visiting members of the IFSW and other tourists. The narrator assesses this centre as a "sharp contrast" of wealth against the poverty shown. The President tells us this contrast is a metaphor for "contradictions" that are, in his perspective, symbolic of life in "Africa".

The introduction of metaphor opens us up to considering other metaphors present in the text. We may also consider the President as a metaphor; reading him in this way we may understand him as a representation, or embodiment of professional social work (Davies, 2006; Lange, 2009). As a representational body, his speech mediates and embeds the policies of the IFSW into this digital narrative (Lange, 2009; Lundby, 2008). He shows and tells audience members about the globalization of social work, inducting us into this understanding of social work through our role as audience (Lange, 2009; Lundby, 2008).

\section{Subjectification}

This description of social work shared by the President may be understood as a form of subjectification in which he constitutes views of social workers by virtue of his presentation of meaning in particular ways that require insider knowledge to interpret (Butler, 2004; Davies, 2006). Our capacity to situate 'the President', 'the IFSW', and 'social work' requires previous knowledge of the IFSW and an understanding about their definition of social work. We also need knowledge about professional social work more generally in order to make good meaning from this story. The more situated our knowledge is, the more deeply meaning can be made from the content of this story; the more we know about the IFSW, the more we can actualize the intended meanings of World Social Work Day 2010 (Lange, 2009; Lundby, 2008).

\section{Place}

The concept of 'place' holds an important role in the IFSW's making of global social work (Razack, 2005). In describing the 'place' he is standing as he does, the President is making claims about the importance and necessity of social work. Here, place helps to both support these claims and create a sense of urgency about the need to globalize social work (Heron, 2007; Hoy, 2005). Ambiguity plays a part in the claims making and place making that is narrated into existence (Bennet \& Edelman, 1985). The President claims a particular space, assigns meaning to it and yet does not consistently explain nor specify the meaning he ascribes. He describes this 'place' in many ways: as a "slum", "the Mathare slum", "Mathare", "Nairobi", "Kenya", and simply as "Africa", moving back and forth between the general and the specific. This lateral movement tells us a great deal, much of which is conveyed through what is not spoken about. In this construction of place, the President never mentions race, poverty, politics, colonialism, globalization, or policies like structural adjustment (Hake \& Ross, 1969; Hay \& Harris, 2007). Africa is made a social work "challenge" without naming specific social issues. At times, this 'place' is made an object, at other times a subject. Social workers are also encouraged to substitute other places and other troubles for this place and these troubles, a request that assumes 
a shared (and perhaps universal) understanding of what constitutes the challenge presented by the President (Bennet \& Edelman, 1985).

\section{Professionalism, Position, and Power}

The President of the IFSW garners particular kinds of power through his position, suggesting this address is a political speech (Lange, 2009). As President of the IFSW, this narrator is a social work power broker; what he says and does holds greater authority than similar actions by other social workers (Adams et al., 2009; Baines, 2011; Heron, 2007; Razack, 2005). Viewers may understand the President of the IFSW as the most powerful social work subject in the world of institutionalized social work and thus, this digital story can be understood as one of the most important institutional social work stories on the Internet.

The implied power of the role of President in a global social work organization presents us once more with ambiguity as a political act. The ambiguous nature of the claims made by the President hold greater meaning than similar claims undertaken by other less powerful people, illustrating how position, power and meaning are linked. This use of ambiguity leaves the audience with the need to interpret a coherent narrative out of the context and content of this story; however the process of making coherence is strongly influenced by the IFSW's power to create meaning in social work contexts (Lange, 2009; Fook, 2002; Fraser, 2004).

The ambiguous use of the term "Africa" suggests that specific knowledges, for example, knowledge of the towns, regions, and national boundaries of the continent of Africa is unnecessary or unimportant to professional global social work and social workers. Specific knowledge is made unimportant because of the vagueness practiced by the President whose business it would seem, is identifying what is important in and about social work. Thus, vagueness becomes, through example, something done by professional social workers, a social work practice so to speak.

In attempting to clarify the ambiguity using intertextual knowledge, viewers might understand the IFSW's message as, 'Africa is a place where social work should be practiced, the kind of social work recognized by the IFSW'. In this way, the IFSW suggests Africa's problems may be (in part) the result of the lack of social work. Furthermore, the implication of the President's earlier claims about contradictions and challenges of "Africa" suggests that social work and social workers are needed in this place. In this way, the IFSW claims Africa as a new social work place and makes future human service activities in Africa the result of the IFSW's introduction of professional social work to this place (Heron, 2006, Spivak, 2004). Therefore, we may read this statement as a kind of neo-colonial activity.

\section{Analyzing Voice}

Multi-modal analysis considers the importance of sound and 'audio' as communication modes that give digital stories 'voice' (Baldry \& Thibault, 2006; Lange, 2009). Like the visual elements, the sound in this digital media story is minimal. The voice of the story consists mainly of the President's verbal statements and a few seconds of background noise. While what the narrator says, the words he chooses are important, inflection, tone, intonation, and accent tell us 
more than his words alone. They make meaning in a way that written texts cannot; this presentation suggests the need to engage in question posing as a tool of inquiry. Audiences might ask:

If the interpretation of the president's accent as a 'British accent' a correct reading? If so, how does this shape the meaning of who The President is in relation to the practice of social work in Kenya?

In this story, audience members hear a British sounding man describing a slum in Kenya. This man holds institutional power. His position allows him to frame the meaning of social work practice in more than 80 countries. He does this without acknowledging the effects of British colonial rule, effects tangibly displayed behind him, but never acknowledged. However, even without acknowledgement, these effects are present; his accent brings the Empire to this scene and gives it voice in the story (Heron, 2007; Lovrod, 2005). While this moment may be an act of atonement, it may also be a neo-colonial moment or perhaps both simultaneously. This moment can be further read as a metaphor of much of the history of social work... should we choose to remember the colonial aspects of our profession's past. This requires us to consider both the context of this situation and the context of social work culture as present in the IFSW's celebration of World Social Work Day (Baldry \& Thibault, 2006; Heron, 2007; La Rose, 2012; Mullaly, 2010; Pon, 2009; Razak, 2005).

\section{Addressing Audience[s]}

The President's address is presented as a personal message to the YouTube audience. This message is as much a matter of recognition as it is sharing of information. This recognition is the "being seen by the other and the self as the desired subject" that post-structuralists describe as the making of identity (Davies, 2006, p. 426); relating to the IFSW is a form of subjection because it means relating as a professional social worker. If being a social worker is viewed as a desirable identity, then the President's message says, 'I want you'. The IFSW 'heralds' the social work community and allows many different social workers to answer the call (Butler, 2004; Davies, 2006; Lange, 2009). What is unclear is if the President is addressing all social workers or if this is a call to a particular group of social workers.

As the IFSW's address continues, the President raises the issue of a pending social work conference. He casually mentions "the conference", as though we must already know about the event. He keeps us in suspense by not telling us which conference he means and not telling us what this conference means to social workers around the globe. As his discussion of the conference continues, the President mentions its location in Hong Kong as a place where the 'new' social work agenda will be created. An alternative to attending, the conference is offered through the president's suggestion that those who cannot make it to Hong Kong may watch the conference 'live' in Hong Kong via the Internet.

\section{Analyzing Discourse}

The IFSW's address activates many discourses; discourses we can elect to take up or disregard in our consideration of the digital story. For example, viewers are presented with the 
idea of "at risk places" when we are told about the Mathare slum. Spivak's (1985) work frames the concept of 'risk' when applied to people and places as an echo of capitalism, stock markets, and 'futures' trading practices. In a neo-liberal world, risk requires attention; it must be controlled and 'managed' because of its potential to interfere with efficiency and profit making (Smith, 2010, 2011; Spivak, 2004). The President's description of the Mathare slum as one of the 'biggest in Africa' activates these quantitative understandings; numbers make this place more worthy of attention.

This use of quantification makes risk more recognizable to powerful people who can potentially help actualize the mandate of the IFSW. Presented in this way, the danger of the slum is made readable for this audience. The anticipated audience is not simply social workers, but people who control money and resources for international development work. Thus, the President uses his position and its power to speak to those who can bring about change from an inter-governmental or investment-based location. In doing so, he is activating elements of the human rights discourse and the IFSW's mandate of collaboration with the United Nations (Hick, 2001; IFSW, 2005).

However, the traps in the human rights discourse make this discourse complicated and shows the inherent contradictions. However, the process of 'making things right' requires 'making things wrong' and both 'wronging' and 'righting' require expert knowledge (Ringrose \& Walkerdine, 2008; Spivak, 1985, 2004). The need for expertise means the white knights of the West are required to step in, placed in the position of expert by those who are positioned to certify expertise and to declare what is wrong and how it must be fixed (Spivak, 2004). This solution generally requires the involvement of the West, which takes the form of people, instructions, resources, and rules assembled from a global context, which really means the West (Hay \& Harris, 2007; Spivak, 1985, 2004).

The IFSW appears to be positioned to take on this role certifying, naming, claiming, and solving, using social work processes and professional social workers to do this work - to make wrong and to make right. Behind the President, the slum unleashes the potential of a "new" social work "making right" project. However, this social work "righting of wrongs" comes layered on top of other projects of "right making," which have produced the slum (Hake \& Ross, 1969; Hay \& Harris, 2007; Stockwell, 2006). These other projects are some of the other possible readings of the slum available to audiences, possibilities not presented in this story. This could, for example, also understand the Mathare slum as a marker of the displacement of industrial workers, the withdrawal of British colonial rule, the legacy of "Structural Adjustment" enforced by the International Monetary Fund, and the ebb and flux of 'new' industrial activities, such as the work of Gulf Oil (Hake \& Ross, 1969; Hay \& Harris, 2007; Stockwell, 2006).

Throughout this digital story, The President is positioned as a kind of bridge between the slum and a "hospitality and tourism training centre". Visually, the slum is behind him and thus can be read as a metaphor of what might become the past (Lakoff \& Johnson, 1980), a past he suggests will be created by social workers. These visual elements layered on top of what the President is saying activates Spivak's (1985) notion of the "modern idealist" (pg. 73); here idealism is a project where globalizing organizations make "internal political philosophy" the goal of "foreign policy" (Spivak, 1985, p. 73). Thus, change becomes a kind of ideological social 
transformation, facilitated through global policies like, for example, the UN Convention on Human Rights that the IFSW upholds (Hick, 2001; IFSW, 2011; Nossal, 2007). In Spivak's (1985) view, this becomes "pressure from above" in the process of change making (p. 73).

Spivak (1985) argues idealism is really a "capitalist ideal" (p. 73). Here considerations of the slum are reframed in terms of ideas like 'untapped human capital' (Jackson \& Jordan, 2000) and the potential value of the land taken up by the slum (George, 2006; Hay \& Harris, 2007). In unpacking the idea of human capital, the concept of "labour power" becomes important. Here "labour power" must be understood "not [as] work" but rather as the potential value of labour "once used" (Spivak, 1985, p. 73). Part of this value is the value of what labour power actualizes in making material the potential of the "creativity of capital" (Spivak, 1985, p. 73).

In this view, untapped labour power is a resource waiting to be spent. The potential value of this labour power is the anticipated gap between the cost of the labour and the value of its production. There is a lot of labour power in the Mathare slum and it appears to be quite reasonably priced, cheap enough to make hospitality work seem like a luxury and training in this area to be a value added activity. There is trouble in the idea of training, training in this kind of industry, and training as a remedy for slums (Jackson \& Jordan, 2000).

Social workers are another part of the labour power the President identifies inducted by the very presence of this ambiguity. Slum dwellers can become hospitality and tourism workers with social workers' support and social workers can make this their work, their 'challenge' with the support of the IFSW. There is perhaps even some loose understanding, based on the mandate of the IFSW, that slum dwellers can be social workers and continue to work in their community in ways recognized by the IFSW should they elect to become 'professional' social workers (IFSW, 2010). Perhaps when next we see the IFSW in the foreground of the slum, a school of social work may be strategically placed next to the hospitality-training centre.

\section{Connections across Texts}

The IFSW's digital media story World Social Work Day 2010 demonstrates the potential of digital texts to convey intended and unintended meanings to anticipated and unanticipated audiences. The benefits of these digital media practices include their potential to allow social workers to share ideas and make connections across time and space and to engage in this sharing quickly, easily, and at a relatively low cost (Kidd, 2010). However, these benefits may become challenges when we consider the importance of situated meanings in producing the desired effects and outcomes of story sharing.

Digital media allows for unexpected and unintended audiences to access these materials, which means texts may have meaning beyond their authors' intent. Clearly, the range of views expressed here go well beyond the apparent intentions of IFSW's digital story. This range of potential meanings supports the need for the use of research methods, such as multi-modal analysis in the study of social workers' use of digital media. The process of deconstruction embraced by this approach encourages careful consideration of a wide range of possible social work discourses activated in story texts. Consideration of discourses in this way is a powerful tool for worker reflection and reflexive practice, bringing to life critical traditions in social work. 
Multi-modal analysis applied in this manner enhances our potential to use digital media stories to understand social work as a pastiche rich with tension, contradictions, and convergence of meanings. Practices advocated in the digital communication and Internet research scholarship support readings of texts that create connections to other digital texts (Baldry \& Thibault, 2006; Dicks et al., 2005; Markham \& Baym, 2009). This kind of intertextual reading allows us to consider the situated nature of the meanings present in the texts and in the social situations in which social workers currently work.

These digital connections can be made between the President's discussion of hospitality and tourism training and the experiences of hospitality workers around the world. While he suggests that the backdrop of the slum is the metaphor for challenge, critical social workers might as easily understand the spectre of the training centre solution as posing a different kind of challenge for social workers. Because YouTube is a repository of many digital texts on a wide array of topics, considering connections based on this analysis can be an almost instantaneous act (Snickars \& Vondreau, 2009). On this basis, the concept of "hospitality workers" was used to conduct a keyword search within YouTube. In attempting to explore these connections, this key word search returned results containing more than 3000 English language videos about hospitality and tourism workers' global experiences. Rather than presenting hospitality work as a form of positive social change as World Social Work Day 2010 suggests, many of the 3000 digital stories on YouTube tell tales of abuse within the sector.

Through these stories about hospitality and tourism workers, viewers become audience to more experiences of poverty and exploitation, as well as stories about the occupational dangers present in this work. These narrative show workers who suffer illness due to exposure to chemicals and who suffer debilitating injuries due to the physical nature of this work (Hotel Workers Rising, 2011; Lee \& Krause, 2002; Lundberg \& Karlsson, 2011; Pearson et al., 2007). The materials contained in these stories suggest to us that the making right presented by the President may very well be another making wrong.

A further search within the digital stories about hospitality and tourism workers provides information about the role that advocacy groups, unions, and associations play in challenging such working environments. These digital stories present visual images of protests, campaign events, and labour actions, calling into question the realities faced by hospitality workers at the global level (Hotel Workers Rising, 2011). Unlike the training into hospitality presented by the IFSW, these movements are challenging the current reality, a challenge that social workers could actively engage with as an expression of our desire to create social change at the global level, a challenge that may allow social workers to work "globally" through actions undertaken locally.

\section{Conclusion}

Reading World Social Work Day 2010 through multi-modal analysis demonstrates the complex nature of digital story texts and the effect that digital media sharing has on the meaning of these texts. In undertaking this project, it is doubtful the IFSW was aware of or might have anticipated the complexity they were working with as they created this digital narrative text. Imagined or not, the pastiche of understanding brought to life through World Social Work Day 
2010 suggests the dubiousness of attempting to promote a unitary understanding of social work, particularly at the global level. The poly-contextual nature of the Internet and the connections created between and across digital texts in the YouTube environment makes the closed meaning required to lay the claims the IFSW seeks to make in this narrative almost impossible. Multimodal analysis of World Social Work Day 2010 suggests that every claim made may be undone by the capabilities of hypermedia technology and the YouTube environment in an era of poststructural theorizing. The IFSW's attempt to produce fixed meaning becomes an invitation to deconstruction rather than facilitating a singular recognition and/or meaning.

The many possible readings of this text and the reality of poly-contextuality suggests that digital media and digital storytelling have great potential as social work practices. There is a need to gain greater knowledge and understanding of digital media if these capacities are to be harnessed to serve our purposes. Experimentation and experiential learning are important ways and means of gaining the kind of critical media literacy necessary to work effectively with digital media narratives. The analysis presented here also suggests the importance of post-structural and postmodern perspectives as ways of knowing about social work that may create new possibilities for social workers around the world, providing counter-arguments to the discourses of neoliberalism, globalization, and professionalization, discourses that move us away from our social justice and social change oriented goals and identities. 


\section{References}

Adams, R., Dominelli, L., \& Payne, M. (2009). Critical practice in social work (2nd ed.). New York, NY: Palgrave.

Baines, D. (Ed.) (2011). Doing anti-oppressive practice: Building transformative politicized social work (2nd ed.). Black Point, NS: Fernwood Publishing.

Baldry, A. \& Thibault, P. (2006). Multimodal transcription and text analysis: A multimedia toolkit and course book with associated on-line course. Oakville, ON: Equinox.

Bennet, W. \& Edelman, M. (1985). Homo narrans: Towards a new political narration. Journal of Communication, (August), 156-171.

Butler, J. (2004). Doing justice to someone: Sex reassignment and allegories of transexuality. GLQ: A Journal of Gay and Lesbian Studies, 7(4), 621-636.

Boler, M. (2008). The politics of making claims: Challenges of qualitative web-based research. In K. Gallagher (Ed.), The methodological dilemma: creative, critical and collaborative approaches to qualitative research, (pp. 11-33). Toronto, ON: Routledge.

Daniels, J. (2009). Rethinking cyberfeminism(s): Race, gender, and embodiment. WSQ: Women's Studies Quarterly, 37(1 \& 2), 101-124.

Davies, B. (2006). Subjectification: The Relevance of Butler's analysis for education. British Journal of Sociology of Education, 27(4), 425-438.

Dicks, B., Mason, B., Coffey, A., \& Atkinson, P. (2005). Qualitative research and hypermedia: Ethnography for the digital age. Thousand Oaks, CA: Sage Publications.

Fitch, D. (2005). The diffusion of information technology in the human services. Journal of Teaching in Social Work, 25(1), $191-204$.

Fook, J. (2002). Social work: critical theory and practice. Thousand Oaks, CA: Sage Publications.

Fraser, H. (2004). Doing narrative research analysing personal stories line by line. Qualitative Social Work, 3(2), 179-201.

George, P. (2006). Experiences in social action with pavement dwellers. In B. Lee \& S. Todd (Eds), Community-based social work: Problems and strategies, (pp. 192198). Toronto, ON: Commonact Press.

Hake, A., \& Ross, M. (1969). Local problems and policies in Mathare. International Social Work, 12(3), 49-69.

Hay A., \& Harris, R. (2007). 'Shauri ya Sera Kali': The colonial regime of urban housing in Kenya to 1939. Urban History, 34(3), 504 - 530. doi:10.107/5096392680700497x.

Heron, B. (2007). Desire for development: Whiteness, gender, and the helping imperative. Waterloo, ON: Wilfred Laurier University Press.

Hick, S. (2001). Social work in Canada. Toronto, ON: Thompson Educational Publishing.

Hick, S., \& McNutt, J. (2002). Advocacy, activism and the Internet: Community organization and social policy. Chicago, IL: Lyceum. 
Hotel Workers Rising. (2011). News and Press [Fact Sheet: Why House Keeping is Dangerous Work]. Retrieved from:

http://www.hotelworkersrising.org/media/Why\%20Housekeeping\%20is\%20Dang erous \%20Work.pdf

Hoy, D.C. (2005). Critical resistance: From poststructuralism to post-critique. Cambridge, MA: The MIT Press.

International Federation of Social Workers [IFSW]. (2011): Organizational Website. Downloaded: (October 20, 2011) http://www.ifsw.org/p38000060.html

Jackson, N. S., \& Jordan, S. (2000). Learning for work: Contested terrain? Studies in the Education of Adults, 32(2), 195-211.

Kellner, D. \& Share, J. (2006). Toward critical media literacy: Core concepts, debates, organizations, and policy. Discourse: Studies in the Cultural Politics of Education, 26(3), 369-386..

Kidd, D. (2010). Whistling into the Typhoon. In, Hughes, C. et al (eds.). In the middle of a whirlwind. Oakland, CA: AK Press. Downloaded (November 12, 2014): https://www.academia.edu/1196052/Whistling_into_the_typhoon_a_radical_inqui ry_into_autonomous_media

Lakoff, G., \& Johnson, M. (1980). Metaphors we live by. Chicago, IL: University of Chicago Press.

Lambert, J. (2008) Digital storytelling: Capturing lives, creating community. San Francisco, CA: Life on the Water Incorporated.

Lange, P. (2009). Videos of Affinity on YouTube. In, P. Snickars \& P.Vondreau (eds.). The YouTube reader,. (pp. 70 -87). Stockholm: National library of Sweden.

La Rose, T. (2012). Digital stories through the lens of multi modal analysis: A case study of Erahoneybee's "Song About a Child Welfare Agency". Journal of Human Services and Technology, 30(3/4), 299 -311.

Lee P.T. \& Krause, N. (2002). The Impact of a worker health study on working conditions. Journal of Public Health Policy, 23(3), 268-285.

Lovrod, M. (2005). Shifting contexts, shaping experiences: Child abuse survivor narratives and educating for empire. Meridians: Feminism, Race, Transnationalism, 5(2), 30-56.

Lundby, K. (2008). Digital storytelling, mediatized stories: Self-representations in new media. New York, NY: Peter Lang.

Lundberg, H. \& Karlesson J. (2011). Under the clean surface: Working as a hotel attendant. Work, Employment and Society 25(1), 141-148.

Markham, A. \& Baym, N. (2009). Internet inquiry: Conversations about method. Los Angeles, CA: Sage.

McNutt, J. (2000). Organizing cyberspace: Strategies for teaching about community practice and technologies. Journal of Community Practice, 7(1), 95-109.

Mullaly, B. (2010). Challenging oppression and confronting privilege, $\left(2^{\text {nd }} \mathrm{ed}\right.$.). Toronto, ON: Oxford University Press.

Nossal, K. (2007). Right and wrong in foreign policy 40 years on: Realism and idealism in Canadian foreign policy. International Journal, 62(2), 263-277.

Pearson, D., Angulo, A., Bourcier, E., Freeman, E., \& Valdez, R. (2007). Hospitality workers' attitudes and exposure to secondhand smoke, hazardous chemicals, and working conditions. Public Health Reports, 122(5), 670-678. 
Pon, G. (2009). Cultural competency as new racism: An ontology of forgetting. Journal of Progressive Human Services, 20(1), 59-71.

Razack, N. (2005). Bodies on the move: Spatialized locations, identities and nationality in International social work. Social Justice, 32(4), 87-104.

Reinsborough, P. \& Canning, D. (2010). Re: imagining change: How to use story-based strategy to win campaigns, build movements, and change the world. San Francisco, CA: PM Press.

Richardson, L. (2000). Writing: A Method Of Inquiry. In, Denzin \& Lincoln (eds). Handbook of qualitative inquiry, (2nd ed.), (pg. 516 - 529). Thousand Oaks, CA: Sage.

Ringrose, J. \& Walkerdine, V. (2008). Regulating the abject: The TV make-over as site of neo-liberal reinvention toward bourgeois femininity. Feminist Media Studies $8(3), 227-246$.

Rosenberg, S. (2004). An introduction to feminist poststructural theorizing. In, Nancy Mandell (ed.) Feminist issues: Race, class and sexuality, (4th ed.), (pg. 35 - 57). Toronto, ON: Pearson/Prentice Hall.

Spivak, G. (1985). Scattered speculations on the question of value. Diacritics, 15(4), 7393.

Spivak, G. (2004). Righting wrongs. South Atlantic Quarterly 103 (2/3), 523-581.

Stockwell, A. (2006). British decolonization: The record and the records. Contemporary European History 15(4), 573 - 583.

Snickars, P. \& Vondreau, P. (2009) The YouTube reader. Stockholm: National Library of Sweden.

TheIFSW (creator). (2010, September 12). World Social Work Day 2010. [Video]. Retrieved from: http://www.youtube.com/watch?v=mrJb_1j8t5Q

YouTube Essentials Guide. (2011). Online Manual. Retrieved from http://www.youtube.com/t/about_essentials4 [This link is no longer working. Alternative link: https://www.youtube.com/yt/about/] 